\title{
Roles of Ethylene in the Development of Superficial Scald in 'Cortland' Apples
}

\author{
Zhanyuan Du and William J. Bramlage \\ Department of Plant and Soil Sciences, University of Massachusetts, Amherst, MA 01003 \\ Additional index words. Malus domestica, $\alpha$-farnesene, conjugated trienes, diphenylamine, scald, storage
}

\begin{abstract}
Ethephon and diphenylamine (DPA) were used to examine the role of ethylene production in biochemical changes that precede development of superficial scald on 'Cortland' apples (Malus domestica Borkh.) after cold storage. Treatments modified $\alpha$-farnesene and conjugated triene (CT) accumulations in fruit peel, and their effects on CTs differed depending on whether CTs were measured at $258 \mathrm{~nm}$ (CT258) or $281 \mathrm{~nm}$ (CT281). Ethephon induced rapid and delayed effects on fruit, the former being stimulation of ethylene production and $\alpha$-farnesene and CT accumulation in fruit peel, which could increase scald development, and the latter being a disproportionately higher accumulation of CT258 than of CT281 during prolonged cold storage, which was associated with reduced scald development. DPA treatment at harvest also produced rapid and delayed effects. It immediately reduced ethylene synthesis and $\alpha$-farnesene and CT accumulation. In addition, during fruit storage at $0 \mathrm{C}$, DPA reduced accumulation of CT281 more than that of CT258. The rapid and delayed effects of DPA should contribute to less scald development. These results showed that ethylene probably was involved in effects of ethephon and DPA on scald development and suggest that ethylene has a fundamental role in changes associated with superficial scald development.
\end{abstract}

Superficial scald of apples and pears is believed to be induced by autooxidation of $\alpha$-farnesene to conjugated trienes (CTs) and the associated formation of free radicals (Anet, 1969; Anet and Coggiola, 1974; Chen et al., 1990; Huelin and Coggiola, 1968). Scald can be controlled by inhibiting autooxidation using antioxidants, among which diphenylamine (DPA) is especially effective (Anet, 1974; Huelin and Coggiola, 1970a; Ingle and D'Souza, 1989; Meir and Bramlage, 1988). This hypothesis is based primarily on in vitro studies of $\alpha$-farnesene oxidation in hexane (Anet, 1969), and on correlations between concentrations of $\alpha$-farnesene and CTs in fruit peel with the amount of scald that develops after long-term cold storage of fruit (Anet and Coggiola, 1974; Huelin and Coggiola, 1970a, 1970b; Meir and Bramlage, 1988). Recently, we found that CT concentrations measured as $\mathrm{OD}_{281}-\mathrm{OD}_{290}$ (CT281) of hexane extracts of fruit peel did not always correspond to concentrations measured as $\mathrm{OD}_{258}-\mathrm{OD}_{290}$ (CT258), and proposed that these measurements represent different $\mathrm{CT}$ species $(\mathrm{Du}$ and Bramlage, 1993). Further, while CT281 concentrations usually were correlated positively with scald development, as has been reported often (Huelin and Coggiola, 1970a, 1970b; Meir and Bramlage, 1988), CT258 concentrations were correlated negatively with scald. When these concentrations were presented as the ratio CT258/CT281, high and low ratios usually were associated negatively or positively, respectively, with scald development. We propose that CT281 is converted to toxic (scald-inducing) and nontoxic metabolites, and that CT258 may represent nontoxic metabolites. Therefore, whether scald develops may be determined not only by the formation and accumulation of $\alpha$-farnesene and CT281, but also by the way in which $\alpha$-farnesene is metabolized.

Many factors affect scald development (Brooks et al., 1919; Little and Peggie, 1987; Little et al., 1973; Lurie and Klein, 1992). Some of these can be explained within the previously existing

Received for publication 14 June 1993. Accepted for publication 13 Sept. 1993. Massachusetts Agricultural Experiment Station paper no. 3092. This research was supported in part by Experiment Station project no. 517 and by grant no. US-1525-88 from the United States-Israel Binational Agricultural Research and Development Fund. The cost of publishing this paper was defrayed in part by the payment of page charges. Under postal regulations, this paper therefore must be hereby marked advertisement solely to indicate this fact. scald hypothesis. For example, storing fruit in low $\mathrm{O}_{2}$ concentrations can control scald development, probably by inhibiting oxidation of $\alpha$-farnesene to CT281 (Little et al., 1973; Lau, 1990; Patterson and Workman, 1962). Other aspects of scald development, however, are more difficult to rationalize within that concept, and may be influencing the way in which $\alpha$-farnesene is metabolized. For example, delayed harvest of fruit usually reduces scald development but often does not reduce $\alpha$-farnesene and CT281 concentrations greatly, and we found that delayed harvest resulted in higher CT258/CT281 ratios during fruit storage (Du and Bramlage, 1993), a result suggesting altered $\alpha$-farnesene or CT metabolism.

The role of ethylene in scald development is not clear. Preharvest ethephon sprays have reduced (Couey and Williams, 1973; Greene et al., 1977b; Hammett, 1976; Lurie et al., 1989b; Watkins et al., 1982) and increased (Greene et al., 1974; Windus and Shutak, 1977) scald. Watkins et al. (1993) found that accumulation of $\alpha$-farnesene in fruit peel corresponded with the rate of ethylene production by the fruit. Knee and Hatfield (1981) previously showed that scald can be controlled when ethylene in the storage atmosphere is maintained at very low concentrations. DPA can suppress ethylene production by fruit (Lurie et al., 1989a), so DPA may be affecting scald development in ways other than by suppressing $\alpha$-farnesene oxidation to CT281.

We have conducted a series of experiments to test further our hypothesis that scald development is influenced by the types of $\alpha$-farnesene oxidation products that accumulate (Du and Bramlage, 1993) by examining the effects of ethephon and DPA applied under different conditions. The results suggest a fundamental role of ethylene in scald development.

\section{Materials and Methods}

Four experiments were conducted during 1991-92 using fruit from mature 'Cortland' apple trees grown under usual commercial conditions at the Univ. of Massachusetts Horticultural Research Center, Belchertown, Mass.

Effects of preharvest ethephon sprays (Expt. 1). Ethephon at 0.5 $\mathrm{g} \cdot$ liter $^{-1}$ was sprayed with a hand gun to the drip point to different sets of trees at six about-weekly intervals beginning on 24 Aug. 
There were four single-tree replications of treatment and control at each spray date. Ten days after spraying, $\approx 180$ fruit per tree were harvested. Ten fruit per tree were evaluated for ripeness by testing for starch with an iodine solution, quantifying starch with a pictorial 'Cortland' chart (Williams and Autio, 1991). Ten other fruit per tree were extracted in high-performance liquid chromatography-grade hexane, and ultraviolet absorbance by the hexane extract was used to measure $\alpha$-farnesene and CT concentrations (Du and Bramlage, 1993).

The remaining fruit were stored at $0 \mathrm{C}$ in air for 20 weeks, and then kept at 20C. On the first and seventh day at 20C, 10 fruit per tree were extracted in hexane for $\alpha$-farnesene and CT concentrations. For the 9 Sept. harvest, five fruit per tree were measured daily for 7 days at 20C for ethylene production. Each day the samples were sealed in 4-liter containers for at least $1 \mathrm{~h}$, after which $1 \mathrm{ml}$ of headspace was measured for ethylene by gas chromatography.

After 7 days at $20 \mathrm{C}, \approx 100$ fruit were evaluated for presence of scald. When examining fruit from the 9 Sept. harvest, from each replication 10 fruit were taken that showed no scald, scald on 10 to $33 \%$ of the surface, or scald on $>66 \%$ of the surface. These fruit were extracted in hexane, which was analyzed as above.

Responses to ethephon and DPA applied at harvest (Expt. 2). About 320 fruit per tree were harvested from four trees (replicates) on 10 Sept. Starch tests averaged 1.6, a result indicating that the fruit were still not ripe.

Fruit from each tree were separated randomly into four sublots of 80 fruit each for treatments. One sublot (control) was dipped in a fungicide solution ( $227 \mathrm{~g}$ of $50 \%$ benlate and $454 \mathrm{~g}$ of wettable powder captan in 400 liters of water), and two sublots were dipped in DPA plus fungicide at $2 \mathrm{~g} \cdot$ liter $^{-1}$. On the following day, one of the DPA-treated sublots and also the sublot not treated the first day were dipped in ethephon plus fungicide at $0.5 \mathrm{~g} \cdot \mathrm{liter}^{-1}$.

All fruit were kept at 20C. On the day of harvest and at 3-day intervals for 18 days, 10 fruit per replicate were measured for ethylene production as above and then were extracted in hexane. Hexane extracts for DPA-treated fruit showed some interference at 250 to $300 \mathrm{~nm}$, for which a correction was made in calculating CT concentrations as follows.

DPA increased hexane absorbance between 260 and $295 \mathrm{~nm}$, with maximum at $\approx 285 \mathrm{~nm}$, using $300 \mathrm{~nm}$ as a reference point. DPA treatment increased absorbance of hexane extracts of apples between 260 and $295 \mathrm{~nm}$ for $\approx 2$ weeks. It was assumed that this increase was due to DPA residue, and that the increased absorbances at $281 \mathrm{~nm}$ and $290 \mathrm{~nm}$ in hexane extracts of fruit due to DPA were proportional to the relative absorbances at these wavelengths. The $\mathrm{OD}_{290 \mathrm{~nm}}$ of the control fruit was subtracted from the $\mathrm{OD}_{290 \mathrm{~nm}}$ of the DPA-treated fruit, and the $\mathrm{OD}_{281 \mathrm{~nm}}$ from treated fruit was reduced proportionally to the difference. Two weeks after DPA application, there was no longer a difference in $\mathrm{OD}_{290 \mathrm{~nm}}$ between treated and control fruit.

Responses to ethephon and DPA applied after 10 weeks at $0 C$ (Expt. 3). Fruit from a single tree were harvested on 30 Sept. when starch tests showed that fruit had begun to ripen. They were stored at $0 \mathrm{C}$ in air for 10 weeks and removed for treatment.

Fruit were separated randomly into three sublots of $\approx 65$ fruit each, and these sublots were dipped in water (control), DPA at 2 $\mathrm{g} \cdot \mathrm{liter}^{-1}$, or ethephon at $0.5 \mathrm{~g} \cdot \mathrm{liter}^{-1}$. All samples then were kept at 20C, and, after 1, 2, 3, 4, 6, 8, 10, 12, 14, and 16 days, five fruit from each treatment were measured for ethylene production as above and then extracted in hexane.

For statistical analyses of the results, day of measurement was considered as a random variable to allow the assessment of differences among treatments over the 16-day period.
Responses to DPA applied at the beginning and end of storage at OC (Expt. 4). Fruit were harvested from four trees (replicates) on 30 Sept., when starch tests showed that ripening had begun. Each replicate lot was separated randomly into four sublots of $\approx 100$ fruit each. One sublot (control) was dipped in fungicide (as in Expt. 2), and a second in DPA plus fungicide at $2 \mathrm{~g} \cdot \mathrm{liter}^{-1}$. All fruit then were stored at $0 \mathrm{C}$, and, after 19 or 20 weeks, the third or fourth sublot, respectively, was dipped in DPA plus fungicide at $2 \mathrm{~g} \cdot \mathrm{liter}^{-1}$.

At 20 weeks after harvest, all fruit were transferred to $20 \mathrm{C}$. After 1, 3, 5, 7, and 9 days, 10 fruit per replicate were measured for ethylene production and then extracted in hexane, as above.

Statistical analyses. Data were subjected to analyses of variance and regression, as appropriate. SAS statistical software (SAS Institute, Cary, N.C.) was used for these analyses. All correlation coefficients presented have $\mathrm{df}=23$.

\section{Results}

Preharvest ethephon sprays: effects at harvest. Starch scores of fruit at harvest indicated that at the first three harvests, control fruit were not ripe, and that they became progressively riper during the last three harvests (Table 1). Ethephon sprays 10 days before harvest produced ripe fruit at all harvests, but at the two latest harvests, control and ethephon-treated fruit were equally ripe.

During ripening of the control fruit, $\alpha$-farnesene concentration in the peel increased progressively, but in the ethephon-treated fruit, $\alpha$-farnesene was at a high concentration regardless of harvest date, and even the ripest control fruit did not reach the levels that were found in the treated fruit (Table 1). In the controls, peel concentrations of CT281 and CT258 increased with harvest date, but not equally, since their ratio declined slightly with later harvest. In ethephon-treated fruit, CT281 and CT258 decreased with harvest date, but not equally, since their ratio was highest at the final harvest. Even at the final harvest, CT concentrations remained higher in sprayed than in control fruit. Overall, the CT258/CT281 ratio was $34 \%$ lower in the sprayed than in the control fruit, but at the last two harvests the ratios were equivalent regardless of treatment (Table 1).

Preharvest ethephon sprays: effects after storage. After fruit had been stored for 20 weeks at $0 \mathrm{C}, \alpha$-farnesene concentrations were equal in control and ethephon-treated fruit (Table 2), due primarily to increases in peel concentrations in controls following harvest. Regardless of treatment, however, $\alpha$-farnesene was higher in fruit picked early than late. CT281 concentrations in fruit reflected the $\alpha$-farnesene concentrations, declining with later harvest date. CT258 concentrations did not follow this pattern, increasing with harvest date in controls and decreasing with harvest date in ethephon-treated fruit, but being about twice as high in treated than in control fruit except at the last harvest. The CT258/ CT281 values, which were lower after storage (Table 2) than those in fruit at harvest (Table 1), were higher in the treated than in the control fruit after storage (Table 2), especially for those harvested early. In control fruit, the ratio after storage increased with later harvest, but for ethephon-treated fruit harvest date had no significant effect.

Hexane extracts also were made after fruit had been kept for 7 days at 20C after removal from storage. Since differences between treatments and among harvest dates were similar to those shown in Table 2, the data are not presented. However, overall, after 7 days at $20 \mathrm{C}$, the fruit contained slightly but significantly less $\alpha$-farnesene and CT281 than at removal, while CT258 did not change during this period. Hence, the CT258/CT281 ratio was slightly but significantly higher after 7 days than at removal. In addition, ethylene 
Table 1. Effects of applying ethephon at $0.5 \mathrm{~g} \cdot \mathrm{liter}^{-1} 10$ days before harvest on starch score and hexane extractable components of 'Cortland' apple surfaces at harvest.

\begin{tabular}{|c|c|c|c|c|c|}
\hline \multirow{2}{*}{$\begin{array}{l}\text { Harvest } \\
\text { date }\end{array}$} & \multirow{2}{*}{$\begin{array}{l}\text { Starch } \\
\text { index }^{\mathrm{z}}\end{array}$} & \multicolumn{3}{|c|}{ Concn $\left(\mathrm{nmol} \cdot \mathrm{cm}^{-2}\right)$} & \multirow[b]{2}{*}{ CT258/CT281 } \\
\hline & & $\alpha$-Farnesene & CT258 & CT281 & \\
\hline \multicolumn{6}{|l|}{ Control } \\
\hline 3 Sept. & 2.7 & 12 & 6.2 & 1.7 & 3.77 \\
\hline 9 Sept. & 3.2 & 7 & 4.9 & 1.0 & 4.87 \\
\hline 16 Sept. & 2.9 & 22 & 11.1 & 2.6 & 4.35 \\
\hline 23 Sept. & 4.1 & 25 & 6.7 & 1.9 & 3.56 \\
\hline 30 Sept. & 5.3 & 41 & 9.1 & 3.1 & 3.00 \\
\hline 7 Oct. & 5.8 & 53 & 10.0 & 2.8 & 3.66 \\
\hline \multicolumn{6}{|l|}{ Significance } \\
\hline $\mathrm{L}$ & $* * *$ & $* * *$ & $* *$ & $* * *$ & $*$ \\
\hline $\mathrm{Q}$ & $* * *$ & $* * *$ & $*$ & $* * *$ & NS \\
\hline \multicolumn{6}{|l|}{ Ethephon-treated } \\
\hline 3 Sept. & 4.8 & 75 & 26.1 & 8.7 & 3.00 \\
\hline 9 Sept. & 4.8 & 85 & 20.3 & 7.0 & 2.92 \\
\hline 16 Sept. & 4.8 & 90 & 20.7 & 7.9 & 2.70 \\
\hline 23 Sept. & 5.5 & 136 & 18.0 & 8.6 & 2.10 \\
\hline 30 Sept. & 5.3 & 44 & 9.4 & 3.4 & 2.93 \\
\hline 7 Oct. & 6.1 & 102 & 14.3 & 4.1 & 3.54 \\
\hline \multicolumn{6}{|l|}{ Significance } \\
\hline $\mathrm{L}$ & $* * *$ & NS & $* * *$ & $* * *$ & NS \\
\hline $\mathrm{Q}$ & $* * *$ & NS & $* * *$ & $* * *$ & $* *$ \\
\hline \multicolumn{6}{|c|}{ Analysis of variance } \\
\hline Ethephon (E) & $* * *$ & $* * *$ & $* * *$ & $* * *$ & $* * *$ \\
\hline Harvest (H) & $* * *$ & $* * *$ & $* * *$ & $* * *$ & $* * *$ \\
\hline $\mathrm{E} \times \mathrm{H}$ & $* *$ & $* * *$ & $* * *$ & $* * *$ & $* * *$ \\
\hline
\end{tabular}

${ }^{\mathrm{z}}$ Based on pictorial chart, where 1 to $3=$ immature, 4 to $6=$ mature, and 7 to $8=$ overmature.

$\mathrm{Ns}^{*}, * * * * * *$ Nonsignificant or significant at $P=0.05,0.01$, and 0.001 , respectively; $\mathrm{L}=$ linear, $\mathrm{Q}=$ quadratic.

Table 2. Effects of applying ethephon at $0.5 \mathrm{~g} \cdot \operatorname{liter}^{-1} 10$ days before harvest on hexane-extractable components of fruit surface of 'Cortland' apples at removal from 0C storage and on percentage of fruit with scald at removal and after 7 days at 20C.

\begin{tabular}{|c|c|c|c|c|c|c|}
\hline \multirow{2}{*}{$\begin{array}{l}\text { Harvest } \\
\text { date }\end{array}$} & \multicolumn{3}{|c|}{ Concn $\left(\mathrm{nmol} \cdot \mathrm{cm}^{-2}\right)$} & \multirow[b]{2}{*}{ СТ258/СТ281 } & \multicolumn{2}{|c|}{ Percentage scald } \\
\hline & $\alpha$-Farnesene & CT258 & CT281 & & Removal & 7 days \\
\hline \multicolumn{7}{|l|}{$\overline{\text { Control }}$} \\
\hline 3 Sept. & 92 & 11.5 & 13.4 & 0.87 & 5 & 92 \\
\hline 9 Sept. & 90 & 11.3 & 9.5 & 1.21 & 3 & 89 \\
\hline 16 Sept. & 86 & 11.6 & 8.1 & 1.46 & 3 & 74 \\
\hline 23 Sept. & 68 & 12.5 & 9.1 & 1.40 & 3 & 64 \\
\hline 30 Sept. & 81 & 13.9 & 8.3 & 1.73 & 0 & 53 \\
\hline 7 Oct. & --- & --- & --- & --- & --- & 41 \\
\hline \multicolumn{7}{|l|}{ Significance } \\
\hline $\mathrm{L}$ & $* *$ & $*$ & $* *$ & $* *$ & NS & $* * *$ \\
\hline $\mathrm{Q}$ & $*$ & $*$ & $* *$ & $* *$ & NS & $* * *$ \\
\hline \multicolumn{7}{|c|}{ Ethephon-treated } \\
\hline 3 Sept. & 91 & 26.8 & 11.9 & 2.28 & 70 & 94 \\
\hline 9 Sept. & 90 & 24.9 & 9.4 & 2.69 & 50 & 89 \\
\hline 16 Sept. & 83 & 18.7 & 10.4 & 2.03 & 60 & 95 \\
\hline 23 Sept. & 70 & 20.9 & 11.6 & 1.83 & 55 & 94 \\
\hline 30 Sept. & 83 & 13.1 & 6.5 & 2.03 & 35 & 59 \\
\hline 7 Oct. & --- & --- & --- & --- & --- & 41 \\
\hline \multicolumn{7}{|l|}{ Significance } \\
\hline $\mathrm{L}$ & $* *$ & $* * *$ & NS & NS & $*$ & $* * *$ \\
\hline $\mathrm{Q}$ & $*$ & $* * *$ & NS & NS & $*$ & $* * *$ \\
\hline \multicolumn{7}{|c|}{ Analysis of variance } \\
\hline Ethephon (E) & NS & $* * *$ & NS & $* * *$ & $* * *$ & NS \\
\hline Harvest $(\mathrm{H})$ & $* * *$ & $* * *$ & $* * *$ & NS & $*$ & $* * *$ \\
\hline $\mathrm{E} \times \mathrm{H}$ & NS & $* * *$ & NS & $* *$ & NS & $* * *$ \\
\hline
\end{tabular}

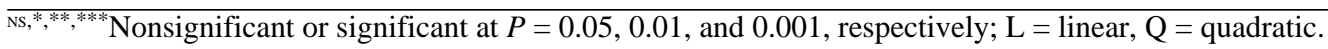


production was measured periodically during the poststorage time, and fruit treated with ethephon before harvest produced only $50 \%$ to $80 \%$ as much ethylene as controls (data not shown), a result suggesting that they were further in the postclimacteric period than controls.

Scald was present on a high percentage of ethephon-sprayed fruit at removal from storage, whereas few of the control fruit exhibited the disorder (Table 2). After 7 days at 20C, controls and treated fruit exhibited much scald. On controls, scald decreased with advancing harvest date, but for ethephon-treated fruit this decrease did not occur until the last two harvests. Percentage scald after 7 days was correlated significantly with $\alpha$-farnesene, CT281, CT258, and the CT258/CT281 ratio in the peel at that time $(r=$ $+0.45^{*},+0.50^{*},-0.54^{*}$, and $-0.65^{* * *}$, respectively) for controls, but with only CT281 and CT258 $\left(r=+0.61^{* *}\right.$ and $+0.66^{* * *}$, respectively) for the sprayed fruit (data not shown).

At-harvest concentrations of $\alpha$-farnesene and CT281 in the controls were negatively correlated with scald $\left(r=-0.88^{* * *}\right.$ and $0.61^{* *}$, respectively), but the poststorage concentrations were positively correlated with scald $\left(r=+0.45^{*}\right.$ and $+0.50^{*}$, respectively). In ethephon-treated fruit, correlations of those components with scald were similar at harvest $\left(r=-0.27^{\mathrm{Ns}}\right.$ and $\left.+0.82^{* * *}\right)$ and after storage $\left(r=+0.10^{\mathrm{ns}}\right.$ and $\left.+0.61^{* *}\right)$. CT258 was correlated negatively with scald at harvest $\left(r=-0.51^{*}\right)$ and after storage $(r=$ $\left.-0.54^{*}\right)$ for controls, but was correlated positively at both times $\left(+0.65^{* * *}\right.$ and $\left.+0.66^{* * *}\right)$ for ethephon-treated fruit.

Extent of scald development was reflected in the concentrations of hexane-extractable components in the peel (Table 3). Scalded fruit contained less $\alpha$-farnesene, more CT281, and less CT258 than nonscalded fruit. Consequently, scalded fruit had lower CT258/CT281 ratios, and the ratios were lower in the more severely scalded fruit.

Effects of ethephon and DPA applications at harvest. Postharvest application of ethephon at $0.5 \mathrm{~g} \cdot \mathrm{liter}^{-1}$ to fruit, but before ripening began, accelerated the rates of ethylene production and $\alpha$-farnesene, CT281, and CT258 accumulation (Fig. 1). Ethylene and CT281 reached higher maximum concentrations in ethephon-treated than in control fruit.

Treatment with DPA at $2 \mathrm{~g} \cdot \mathrm{liter}^{-1}$ instead of ethephon produced the opposite effects, suppressing ethylene production and the accumulations of $\alpha$-farnesene, CT281, and CT258 (Fig. 1). Maximum concentrations of all of these components was less in DPA-treated than in control fruit. When fruit were treated with ethephon and DPA, ethylene production and $\alpha$-farnesene accumulation increased faster than in controls, but CT281 and CT258 accumulated at about the same rate as in the controls.

During the 18 days at 20C, ethephon treatment increased but DPA treatment decreased production of ethylene and accumulation of $\alpha$-farnesene, CT281, and CT258 in fruit peel (Table 4). When fruit were treated with DPA and then ethephon, overall they produced more ethylene than DPA-treated fruit, but less than ethephon-treated fruit. However, they produced about the same concentrations of $\alpha$-farnesene and CTs as the controls. Therefore, in this combination, DPA and ethephon essentially counteracted each other's effect on ethylene production and on accumulation of $\alpha$-farnesene and CTs, since there were no interactions between ethephon and DPA treatment on any measurements (Table 4).

There was clear correspondence in time among increases in ethylene, $\alpha$-farnesene, and CTs (Fig. 1). From the third day on, ethylene production and accumulation of $\alpha$-farnesene and CTs were different among treatments. During this period, effects of DPA on ethylene production and $\alpha$-farnesene accumulation were overridden by ethephon, but DPA suppression of $\alpha$-farnesene oxidation to CTs was at most canceled out by ethephon. These results indicated that DPA probably had separate effects on ethylene and $\alpha$-farnesene production, and on $\alpha$-farnesene oxidation to CTs.

Effects of ethephon and DPA application after 10 weeks of

Table 3. Hexane extractable components of 'Cortland' apple peel from fruit with different amounts of superficial scald on their surface. Fruit were from the 9 Sept. harvest that had been stored 20 weeks at $0 \mathrm{C}$ plus 7 days at 20C. Ten fruit samples with the indicated scald incidence were selected from each of four replications.

\begin{tabular}{|c|c|c|c|c|}
\hline \multirow{2}{*}{$\begin{array}{l}\text { Surface affected } \\
\text { with scald } \\
(\%)\end{array}$} & \multicolumn{3}{|c|}{ Concn $\left(\mathrm{nmol} \cdot \mathrm{cm}^{-2}\right)$} & \multirow[b]{2}{*}{ CT258/CT281 } \\
\hline & $\alpha$-Farnesene & CT258 & CT281 & \\
\hline \multicolumn{5}{|l|}{ Control } \\
\hline 0 & 119 & 14.1 & 9.2 & 1.54 \\
\hline 1 to 33 & 100 & 12.1 & 10.9 & 1.12 \\
\hline$>66$ & 71 & 9.7 & 10.9 & 0.90 \\
\hline \multicolumn{5}{|c|}{ Significance against scald score ${ }^{\mathrm{z}}$} \\
\hline $\mathrm{L}$ & $* * *$ & $* * *$ & $*$ & $* * *$ \\
\hline $\mathrm{Q}$ & $* * *$ & $* * *$ & $*$ & $* * *$ \\
\hline \multicolumn{5}{|l|}{ Ethephon-treated } \\
\hline 0 & 108 & 36.0 & 8.7 & 4.18 \\
\hline 1 to 33 & 93 & 31.0 & 10.8 & 2.94 \\
\hline$>66$ & 64 & 23.3 & 10.1 & 2.31 \\
\hline \multicolumn{5}{|c|}{ Significance against scald score } \\
\hline $\mathrm{L}$ & $* * *$ & $* *$ & NS & $* * *$ \\
\hline $\mathrm{Q}$ & $* * *$ & $* *$ & NS & $* * *$ \\
\hline \multicolumn{5}{|l|}{ Analysis of variance } \\
\hline Ethephon (ET) & $*$ & $* * *$ & NS & $* * *$ \\
\hline Scald intensity (SI) & $* * *$ & $* * *$ & $*$ & $* * *$ \\
\hline $\mathrm{ET} \times \mathrm{SI}$ & NS & $*$ & NS & $* * *$ \\
\hline
\end{tabular}

${ }^{\mathrm{z}}$ Scald score: $0 \%=0 ; 1$ to $33 \%=1 ;>67 \%=2$.

Ns,*,**,*** Nonsignificant or significant at $P=0.05,0.01$, and 0.001 , respectively; $\mathrm{L}=$ linear, $\mathrm{Q}=$ quadratic. 

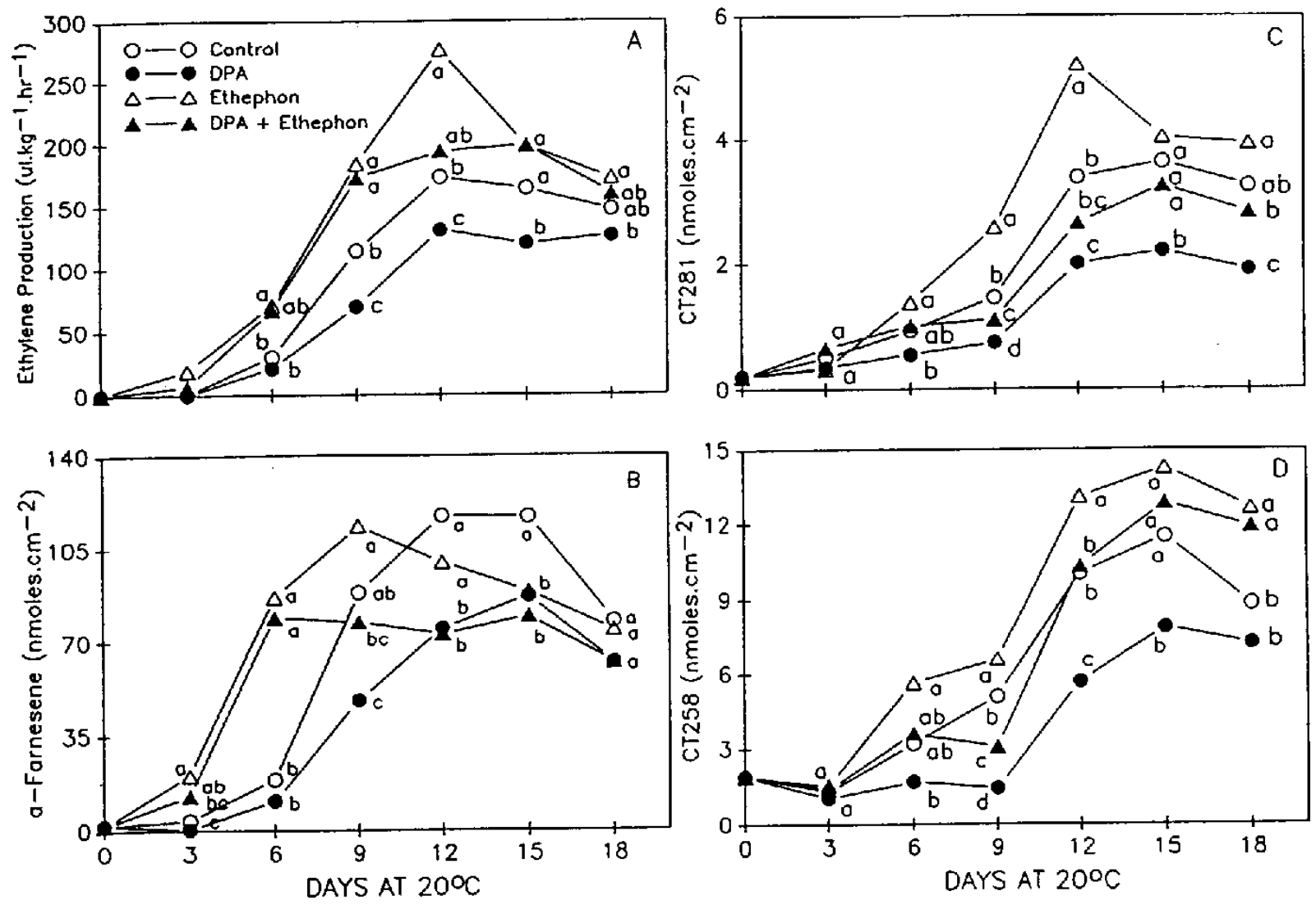

Fig. 1. Effects of applying ethephon $\left(0.5 \mathrm{~g} \cdot \mathrm{liter}^{-1}\right)$ and DPA $\left(2 \mathrm{~g} \cdot\right.$ liter $\left.{ }^{-1}\right)$ at harvest on ethylene production $(\mathbf{A})$ and on accumulation of $\alpha$-farnesene $(\mathbf{B})$, CT281 $(\mathbf{C})$, and CT258 (D) in peel of Cortland apples at 20C without storing fruit at $0 \mathrm{C}$. Means for a day not followed by a common letter are significantly different at $P=0.05$ using Duncan's new multiple range test.

Table 4. Effects of applying ethephon, DPA, or both to 'Cortland' apples at harvest on ethylene production and on hexaneextractable components of fruit surface during 18 days at 20C. Data are combined results of observations in Fig. 1.

\begin{tabular}{|c|c|c|c|c|c|}
\hline \multirow[b]{2}{*}{ Treatment } & \multirow{2}{*}{$\begin{array}{c}\text { Ethylene } \\
\text { production } \\
\left(\mu \mathrm{l} \cdot \mathrm{kg}^{-1} \cdot \mathrm{h}^{-1}\right)\end{array}$} & \multicolumn{3}{|c|}{ Concn $\left(\mathrm{nmol} \cdot \mathrm{cm}^{-2}\right)$} & \multirow[b]{2}{*}{ СТ258/CT281 } \\
\hline & & $\alpha$-Farnesene & CT258 & CT281 & \\
\hline Control & 90 & 61 & 6.0 & 1.9 & 4.14 \\
\hline Ethephon (E) & 124 & 69 & 7.9 & 2.5 & 4.62 \\
\hline DPA (D) & 67 & 41 & 3.8 & 1.1 & 4.16 \\
\hline $\mathrm{D}+\mathrm{E}$ & 114 & 55 & 6.4 & 1.7 & 4.45 \\
\hline \multicolumn{6}{|l|}{ Analysis of variance } \\
\hline $\mathrm{E}$ & $* * *$ & $* * *$ & $* * *$ & $* * *$ & NS \\
\hline $\mathrm{D}$ & $* * *$ & $* * *$ & $* * *$ & $* * *$ & NS \\
\hline Time at 20C (T) & $* * *$ & $* * *$ & $* * *$ & $* * *$ & $* * *$ \\
\hline $\mathrm{D} \times \mathrm{E}$ & NS & NS & NS & NS & NS \\
\hline $\mathrm{E} \times \mathrm{T}$ & $* * *$ & $* * *$ & $* * *$ & $* *$ & NS \\
\hline $\mathrm{D} \times \mathrm{T}$ & NS & $* * *$ & $* * *$ & $* * *$ & NS \\
\hline $\mathrm{D} \times \mathrm{E} \times \mathrm{T}$ & NS & NS & NS & NS & NS \\
\hline
\end{tabular}

storage at $0 C$. Fruit were harvested on 30 Sept. after ripening had begun, stored for 10 weeks at $0 \mathrm{C}$, and then treated with either ethephon at $0.5 \mathrm{~g} \cdot$ liter $^{-1}$ or DPA at $2 \mathrm{~g} \cdot \mathrm{liter}^{-1}$ and kept at $20 \mathrm{C}$ for 16 days. Ethephon increased ethylene production and CT281 accumulation, while DPA decreased ethylene production and $\alpha$-farnesene accumulation, and increased the CT258/CT281 ratio (Table 5). While other differences were not significant, trends were consistent with results at harvest (Table 4). Thus, despite the fact that these fruit already were producing high rates of ethylene, they still remained sensitive to additional production. Overall, after 10 weeks at $0 \mathrm{C}$, the fruit produced about twice as much ethylene and contained substantially greater amounts of $\alpha$-farnesene, CT281, and CT258 than at harvest, and had a much lower CT258/CT281 ratio than at harvest (Table 5 vs. Table 4).

Effects of DPA treatment after different periods of storage. One day after removing fruit from 20 weeks of storage at $0 \mathrm{C}$, none of the DPA treatments affected ethylene production or concentrations of $\alpha$-farnesene or CT258 in peel (Table 6). However, DPA 
Table 5. Effects of applying ethephon and DPA to 'Cortland' apples after 10 weeks of storage at 0C on ethylene production and on hexane-extractable components of fruit surface during 16 days at 20C. Data are combined results of measurements during the 16 days at $20 \mathrm{C}$.

\begin{tabular}{|c|c|c|c|c|c|c|}
\hline \multirow{2}{*}{$\begin{array}{l}\text { Days } \\
\text { at } 20 \mathrm{C}\end{array}$} & \multirow[b]{2}{*}{ Treatment } & \multirow{2}{*}{$\begin{array}{c}\text { Ethylene } \\
\text { production } \\
\left(\mu \mathrm{l} \cdot \mathrm{kg}^{-1} \cdot \mathrm{h}^{-1}\right)\end{array}$} & \multicolumn{3}{|c|}{ Concn $\left(\mathrm{nmol} \cdot \mathrm{cm}^{-2}\right)$} & \multirow[b]{2}{*}{ CT258/CT281 } \\
\hline & & & $\alpha$-Farnesene & CT258 & CT281 & \\
\hline 1 & Control & 125 & 95 & 9.5 & 4.6 & 2.10 \\
\hline \multirow[t]{3}{*}{1 to 16} & Control & 217 & 45 & 10.2 & 4.1 & 2.58 \\
\hline & Ethephon & 232 & 47 & 11.6 & 4.9 & 2.71 \\
\hline & DPA & 200 & 41 & 11.4 & 4.0 & 2.89 \\
\hline \multicolumn{7}{|c|}{ Analysis of variance } \\
\hline \multicolumn{2}{|c|}{ Ethephon vs. 1 to 16 control } & $*$ & NS & NS & $* *$ & NS \\
\hline \multicolumn{2}{|c|}{ DPA vs. 1 to 16 control } & $* *$ & $*$ & NS & NS & $*$ \\
\hline
\end{tabular}

Table 6. Effects of DPA at $2 \mathrm{~g} \cdot$ liter $^{-1}$, applied to 'Cortland' apples at different times, on ethylene production, hexane-extractable components of fruit surface, and scald development. Data are shown as results on day 1 and as combined results of all observations during day 1 through 9 at $20 \mathrm{C}$ after 20 weeks of storage at $0 \mathrm{C}$, except that scald was recorded only after 7 days.

\begin{tabular}{|c|c|c|c|c|c|c|c|}
\hline \multirow{2}{*}{$\begin{array}{l}\text { Days } \\
\text { at } 20 \mathrm{C}\end{array}$} & \multirow[b]{2}{*}{ Treatment } & \multirow{2}{*}{$\begin{array}{c}\text { Ethylene } \\
\text { production } \\
\left(\mu \mathrm{l} \cdot \mathrm{kg}^{-1} \cdot \mathrm{h}^{-1}\right)\end{array}$} & \multicolumn{3}{|c|}{ Concn $\left(\mathrm{nmol} \cdot \mathrm{cm}^{-2}\right)$} & \multirow[b]{2}{*}{ CT258/CT281 } & \multirow{2}{*}{$\begin{array}{c}\text { Scald } \\
(\%)\end{array}$} \\
\hline & & & $\alpha$-Farnesene & CT258 & CT281 & & \\
\hline \multirow[t]{4}{*}{1} & None & 68 & 63 & 9.9 & 7.7 & 1.30 & $\overline{---}$ \\
\hline & $\mathrm{DPA}, 0 \mathrm{wk}$ at $0 \mathrm{C}$ & 66 & 58 & 7.6 & 3.0 & 2.57 & --- \\
\hline & DPA, 19 wk at $0 \mathrm{C}$ & 67 & 60 & 8.8 & 6.5 & 1.34 & --- \\
\hline & DPA, 20 wk at $0 \mathrm{C}$ & 61 & 61 & 8.1 & 5.1 & 1.61 & --- \\
\hline \multirow[t]{4}{*}{1 to 9} & None & 285 & 45 & 10.4 & 6.3 & 1.72 & 21 \\
\hline & DPA, 0 wk at $0 \mathrm{C}$ & 271 & 47 & 8.9 & 3.4 & 2.63 & 1 \\
\hline & DPA, 19 wk at $0 \mathrm{C}$ & 274 & 39 & 8.4 & 5.5 & 1.55 & 9 \\
\hline & DPA, $20 \mathrm{wk}$ at $0 \mathrm{C}$ & 261 & 40 & 9.8 & 5.6 & 1.84 & 13 \\
\hline \multicolumn{8}{|c|}{ Analysis of variance } \\
\hline \multicolumn{2}{|c|}{ Treatment $(\mathrm{T})$} & $*$ & $* * *$ & $*$ & $* * *$ & $* * *$ & $*$ \\
\hline \multicolumn{2}{|c|}{-DPA vs. +DPA } & $*$ & $*$ & $*$ & $* * *$ & $* * *$ & $*$ \\
\hline \multicolumn{2}{|c|}{ Time at $20 \mathrm{C}(\mathrm{W})$} & $* * *$ & $* * *$ & NS & NS & $* * *$ & --- \\
\hline \multicolumn{2}{|c|}{$\mathrm{T} \times \mathrm{W}$} & NS & $* *$ & NS & NS & $*$ & --- \\
\hline
\end{tabular}

treatments reduced CT281 concentrations, with application at harvest having the greatest effect.

During the subsequent 8 days at 20C, ethylene production increased greatly and $\alpha$-farnesene concentrations decreased, but concentrations and ratio of CTs did not change substantially. During this period at 20C, effects of DPA application on all measurements depended on when it had been applied. DPA application at removal from storage slightly depressed ethylene production and $\alpha$-farnesene accumulation but had no consistent effect on CTs. In contrast, DPA application at harvest reduced accumulation of CTs (especially CT281), and increased the CT258/ CT281 ratio but did not reduce ethylene production and $\alpha$-farnesene accumulation, again indicating that DPA had separate effects on ethylene production and $\alpha$-farnesene oxidation. Some scald developed on these fruit, and it was reduced by DPA.

\section{Discussion}

These results generally confirm our earlier findings ( $\mathrm{Du}$ and Bramlage, 1993). First, $\alpha$-farnesene and CT281 concentrations did not correlate consistently with scald development. For example, at-harvest concentrations were negatively correlated with scald while poststorage concentrations were positively correlated in control fruit (Tables 1 and 2). Second, CT concentrations measured at 281 and $258 \mathrm{~nm}$ displayed different results (Tables 1 and 5), a result indicating that different substances are being measured. Further, these substances were associated with scald development in different ways (Table 3 ).

During ripening on the tree, $\alpha$-farnesene, CT281, and CT258 all increased greatly in fruit peel, and ethephon accelerated these increases (Table 1). We shall refer to these increases as rapid effects of ripening. This is in contrast to a delayed effect of ripening on $\alpha$-farnesene metabolism: after fruit had been stored at $0 \mathrm{C}$ for 20 weeks, late-harvested (ripe) control fruit contained less $\alpha$-farnesene and CT281 but more CT258 and therefore a higher CT258/CT281 ratio than early-harvested (unripe) control fruit (Table 2). Further, preharvest ethephon treatment doubled the poststorage CT258 concentrations in all fruit except those from the final harvest, but did not affect their $\alpha$-farnesene or CT281 concentrations (Table 2). Therefore, these data suggest that preharvest ripening, whether it was induced by ethephon, accelerated the synthesis and oxidation of $\alpha$-farnesene, with a relatively high proportion of oxidation products accumulating as CT281. However, when these fruit were stored at $0 \mathrm{C}$ for a prolonged time, they developed the capacity to accumulate substantially higher CT258 concentrations than early-harvested and control fruit, resulting in higher CT258/ CT281 ratios for the late-harvested or ethephon-treated fruit at removal from storage. We have shown previously that relatively 
high CT258/CT281 ratios are associated with relatively low scald development (Du and Bramlage, 1993), and ripening has long been known to reduce scald. We propose that when ripening fruit are stored at low temperature, they metabolize $\alpha$-farnesene differently from ones that are not ripe when stored, and that this difference in metabolism affects scald development. (Alternatively, however, the late-harvested fruit may synthesize CT258 from substrates other than $\alpha$-farnesene.)

Ethephon treatments accelerated but did not alter substantially the changes in $\alpha$-farnesene and CT281 associated with ripening (Table 1) or the differences after 20 weeks at 0C associated with different harvest dates (Table 2). Both of these rapid and delayed effects of ripening therefore may represent ethylene effects on $\alpha$-farnesene synthesis and metabolism in fruit peel. This is indicated also by the sequence of responses to ethephon at harvest time (Fig. 1). Accelerated ethylene production was advanced by 3 days, as was increased $\alpha$-farnesene concentration. CT281 and CT258 concentrations also were increased by ethephon, but differences were not seen until day 9. In controls, these same responses occurred but they required more time to develop. These results are consistent with those of Watkins et al. (1993), who found that $\alpha$-farnesene and CT281 concentrations rose as ethylene production by 'Granny Smith' apples increased. It should be noted also that, with later application times, ethephon produced smaller increases in $\alpha$-farnesene, CT281, and CT258 concentrations (Tables 1,4 , and 5), probably because climacteric ethylene production was already stimulating production of these compounds.

The role of DPA in $\alpha$-farnesene oxidation in apple peel seems to be more complex than is implied from the studies of its oxidation in hexane. In hexane, 33 to 66 weeks were required for DPA to inhibit $\alpha$-farnesene oxidation (Huelin and Coggiola, 1970a), but in apple peel, effects can be seen in a few days (Fig. 1 and Table 6). Also, in hexane a wide range of antioxidants (amine, phenolic, and sulfur-containing) inhibited $\alpha$-farnesene oxidation, while in apple peel only amine-type antioxidants were inhibitory, with some phenolic antioxidants even acting as pro-oxidants (Anet and Coggiola, 1974). DPA can inhibit many reactions, such as electron transport (Baker, 1963) and ethylene production, respiration, and enzyme activities (Lurie et al., 1989a).

DPA suppression of ethylene production was prominent in our experiments. When applied at harvest, DPA reduced ethylene production during the climacteric by $\approx 20 \%$ (Table 4 ) and reduced $\alpha$-farnesene and CTs substantially. Thus, significant reductions of CT281 by DPA probably resulted from lower concentrations of $\alpha$-farnesene, its precursor.

Even after fruit were stored for 10 (Table 5) or 20 (Table 6) weeks, when they were producing high rates of ethylene, DPA reduced ethylene and $\alpha$-farnesene. In addition to reducing ethylene production, DPA also inhibited CT281 accumulation, as occurs in hexane (Huelin and Coggiola, 1970a). When fruit treated at harvest were measured after 20 weeks at $0 \mathrm{C}$, they contained only $\approx 40 \%$ as much CT281 as controls, even though their ethylene production and $\alpha$-farnesene concentrations were by then equal to those of controls (Table 6). However, DPA was less effective in inhibiting CT281 when it was applied after 10, 19, and 20 weeks at $0 \mathrm{C}$ (Tables 5 and 6).

Results of these experiments can be pictured as in Fig. 2, which is slightly modified from our earlier model ( $\mathrm{Du}$ and Bramlage, 1993), where $X$ is the substrate for $\alpha$-farnesene synthesis and $Z$ is the presumed toxic compound that causes scald lesions to form. CT281 and CT258 seem to be separate species or groups of species of $\alpha$-farnesene oxidation products, presumably both CTs. While CT281 seems to lead to scald development, CT258 seems to have

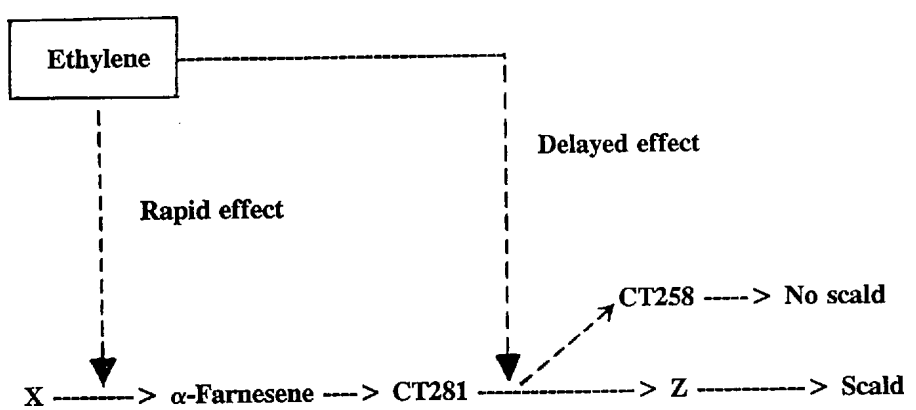

Fig. 2. Proposed model of ethylene-mediated effects on synthesis of $\alpha$-farnesene and its metabolism and on scald development.

a protective effect against scald development, since greater concentrations were associated with less scald development.

The rapid effects of ethylene on scald development are viewed as ethylene-enhanced $\alpha$-farnesene synthesis and probably include more rapid flux of the entire sequence, with CT281 accumulation slightly favored over that of CT258, producing slightly reduced CT258/CT281 ratios (Table 1; Du and Bramlage, 1993). The delayed effects of ethylene are expressed as greater accumulation of CT258 than of CT281 late in storage. The rapid effects would favor scald development and the delayed effects would disfavor it. Effects of DPA on the model—reduced $\alpha$-farnesene synthesis and inhibited $\alpha$-farnesene oxidation to CT281 - should lessen scald development.

Whether scald symptoms develop on a fruit would be determined by the balance that develops between the rapid and delayed effects of a particular condition. Applying ethephon preharvest to 'Cortland' apples produced high $\alpha$-farnesene and CT concentrations before harvest, whereas applying it to 'Granny Smith' apples had only slight effects (unpublished data). The difference may result from much greater ethylene production by 'Cortland' than 'Granny Smith' (Watkins et al., 1993). Ethephon caused scald to develop sooner than on 'Cortland' controls (Table 2), and it overrode some of the ameliorating effect of delayed harvest (Table 2; 16 and 23 Sept. harvests). Ameliorization by delayed harvest may result from enhanced delayed effect of ripening, since the CT258/CT281 ratio after 20 weeks at 0C rose with later harvest of control fruit (Table 2). This ratio apparently had significance in individual fruit because, whether they were treated with ethephon, fruit with increasing amounts of scald on them exhibited decreasing CT258/CT281 ratios (Table 3).

These findings may explain some of the conflicting reports on scald development under different experimental conditions. For example, applying ethephon to 'Delicious' (Couey and Williams, 1973; Greene et al., 1977b; Hammett, 1976) and 'Granny Smith' (Lurie et al., 1989b; Watkins et al., 1982) reduced scald, while applying it to 'Cortland' (Windus and Shutak, 1977) and 'McIntosh' (Greene et al., 1974) increased it. Since 'Delicious' and 'Granny Smith' produce less ethylene than 'Cortland' and 'McIntosh', ethephon should result in much less $\alpha$-farnesene and CT accumulation than in 'Cortland' and 'McIntosh'. Greene et al. (1977a) also found that midsummer ethephon applications to 'McIntosh' only modestly increased ethylene production and, while it caused earlier fruit ripening, it did not increase scald.

Brooks et al. (1919) ranked fruit maturity (time of harvest) as the most important of 16 factors or treatments that affect scald development. While effects from more advanced maturity often are confounded with those from greater exposure to low preharvest temperature (Barden and Bramlage, 1994), results presented here 
suggest that prestorage ripening alters $\alpha$-farnesene metabolism late in storage at $0 \mathrm{C}$, favoring accumulation of CT258 over that of CT281 and lessening likelihood that scald lesions will form.

In summary, ethylene seems to be critically involved in scald development, stimulating accumulation of $\alpha$-farnesene and CTs in fruit peel. In assessing effects of different conditions on scald development, ethylene synthesis needs to be examined. In addition, ethylene production or ripeness of fruit at the time they are placed in storage seems to affect the levels of CTs that accumulate in fruit peel late in storage, perhaps by affecting the way in which $\alpha$-farnesene is metabolized. How a given condition or treatment will affect scald development may be determined by the balance it produces between these rapid and delayed responses to ethylene.

\section{Literature Cited}

Anet, E.F.L.J. 1969. Auto oxidation of $\alpha$-farnesene. Austral. J. Chem. 22:2403-2410.

Anet, E.F.L.J. 1974. Superficial scald, a functional disorder of stored apples. XI. Apple antioxidants. J. Sci. Food Agr. 25:299-304.

Anet, E.F.L.J. and I.M. Coggiola. 1974. Superficial scald, a functional disorder of stored apples. X. Control of $\alpha$-farnesene autooxidation. J. Sci. Food Agr. 25:293-298.

Baker, J.E. 1963. Diphenylamine inhibition of electron transport in plant mitochondria. Arch. Biochem. Biophys. 103:148-155.

Barden, C L. and W.J. Bramlage. 1994. Separating the effects of cool temperatures, ripening, and light on loss of scald susceptibility in apples prior to harvest. J. Amer. Soc. Hort. Sci. 119:54-58

Brooks, C., J.S. Cooley, and D.F. Fisher. 1919. Apple scald. J. Agr. Res. 16:195-217.

Chen, P.M., D.M. Varga, E.A. Mielke, T.J. Facteau, and S.R. Drake. 1990. Control of superficial scald on 'd'Anjou' pears by ethoxyquin: Oxidation of $\alpha$-farnesene and its inhibition. J. Food Sci. 55:171-174.

Couey, H.M. and M.W. Williams. 1973. Preharvest application of ethephon on scald and quality of stored 'Delicious' apples. HortScience 8:5657.

Du, Z. and W.J. Bramlage. 1993. A modified hypothesis on the role of conjugated trienes in superficial scald development on apples. J. Amer. Soc. Hort. Sci. 118:807-813

Greene, D.W., W.J. Lord, W.J. Bramlage, and F.W. Southwick. 1974. Effects of low ethephon concentrations on quality of 'McIntosh' apples. J. Amer. Soc. Hort. Sci. 99:239-242.

Greene, D.W., W.J. Lord, and W.J. Bramlage. 1977a. Mid-summer applications of ethephon and daminozide on apples. I. Effects on 'McIntosh'. J. Amer. Soc. Hort. Sci. 102:491-494.

Greene, D.W., W.J. Lord, and W.J. Bramlage. 1977b. Mid-summer applications of ethephon and daminozide on apples. II. Effects on 'Delicious'. J. Amer. Soc. Hort. Sci. 102:494-497.

Hammett, L.K. 1976. Ethephon influence on storage quality of 'Starkrim- son Delicious' and 'Golden Delicious' apples. HortScience 11:57-59. Huelin, F.E. and I.M. Coggiola. 1968. Superficial scald, a functional disorder of stored apples. IV. Effect of variety, maturity, oiled wraps, and diphenylamine on concentration of $\alpha$-farnesene in the fruit. J. Sci. Food Agr. 19:297-301.

Huelin, F.E. and I.M. Coggiola. 1970a. Superficial scald, a functional disorder of stored apples. V. Oxidation of $\alpha$-farnesene and its inhibition by diphenylamine. J. Sci. Food Agr. 21:44-48.

Huelin, F.E. and I.M. Coggiola. 1970b. Superficial scald, a functional disorder of stored apples. VII. Effects of applied farnesene, temperature, and diphenylamine on scald and the concentration and oxidation of $\alpha$-farnesene in the fruit. J. Sci. Food Agr. 21:584-589.

Ingle, M. and M.C. D’Souza. 1989. Physiology and control of superficial scald of apples: A review. HortScience 24:28-31.

Knee, M. and S.G.S. Hatfield. 1981. Benefits of ethylene removal during apple storage. Ann. Applied Biol. 98:157-165.

Lau, O.L. 1990. Efficacy of diphenylamine, ultra-low oxygen, and ethylene scrubbing on scald control in 'Delicious' apples. J. Amer. Soc. Hort. Sci. 115:959-961.

Little, C.R. and I.D. Peggie. 1987. Storage injury of pome fruit caused by stress levels of oxygen, carbon dioxide, temperature, and ethylene. HortScience 22:783-787.

Little, C.R., I.D. Peggie, and H.J. Taylor. 1973. Effect of maturity, carbon dioxide, and storage duration on controlled atmosphere stored 'Jonathan' apples. Austral. J. Expt. Agr. Animal Husbandry 13:593-597.

Lurie, S. and J.D. Klein. 1992. Calcium and heat treatment to improve storability of 'Anna' apples. HortScience 27:36-39.

Lurie, S., J.D. Klein, and R. Ben-Arie. 1989a. Physiological changes in diphenylamine-treated 'Granny Smith' apples. Israel J. Bot. 38:199_ 207.

Lurie, S., S. Meir, and R. Ben-Arie. 1989b. Preharvest ethephon sprays reduce superficial scald of 'Granny Smith' apples. HortScience 24:104106.

Meir, S. and W.J. Bramlage. 1988. Antioxidant activity in 'Cortland' apple peel and susceptibility to superficial scald after storage. J. Amer. Soc. Hort. Sci. 113:412-418.

Patterson, M.E. and M. Workman. 1962. The influence of oxygen and carbon dioxide on the development of apple scald. Proc. Amer. Soc. Hort. Sci. 80:130-136.

Watkins, C.B., C.L. Barden, and W.J. Bramlage. 1993. Relationships among $\alpha$-farnesene, conjugated trienes and ethylene production with superficial scald development of apples. Acta Hort. 343:155-160.

Watkins, C.B., M.S. Reid, J.E. Harman, and A.A.S. Padfield. 1982. Starch iodine pattern as a maturity index for 'Granny Smith' apples. II. Differences between districts and relationships to storage disorders and yield. N.Z. J. Agr. Res. 25:587-592.

Williams, J.T. and W.R. Autio. 1991. Cortland starch chart. Fruit Program, F-104:6/91-500. Univ. of Massachusetts Coop. Ext.

Windus, N.D. and V.G. Shutak. 1977. Effect of ethephon, diphenylamine, and daminozide on the incidence of scald development on 'Cortland' apples. J. Amer. Soc. Hort. Sci. 102:715-718. 